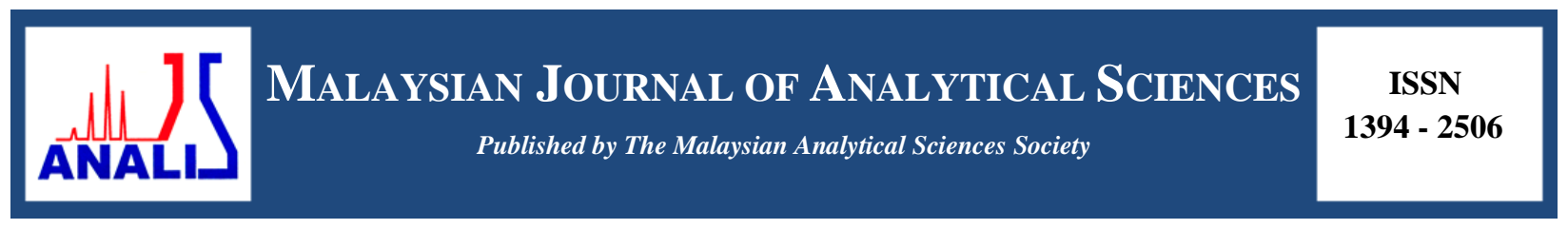

\title{
COMPARATIVE STUDY OF MICROBIAL FUEL CELL'S PERFORMANCE USING THREE DIFFERENT ELECTRODES
}

\author{
(Kajian Perbandingan Bagi Prestasi Sel Bahan Bakar Mikrob Menggunakan Tiga Elektrod yang \\ Berbeza)
}

\author{
Khairul Baqir Alkhair ${ }^{1,3}$, Oskar Hasdinor Hassan², Sharifah Aminah Syed Mohamed ${ }^{1}$,Yap Kian Chung Andrew ${ }^{3}$, \\ Zulkifli Ab. Rahman ${ }^{3}$, Tunku Ishak Tunku Kudin ${ }^{1}$,Ab. Malik Marwan Ali ${ }^{1,4}$, Mohd Zu Azhan Yahya ${ }^{5}$, \\ Muhammad Haikal Zainal $^{1}$ \\ ${ }^{I}$ Faculty of Applied Science \\ ${ }^{2}$ Faculty of Art and Design \\ Universiti Teknologi MARA, 40450 Shah Alam, Selangor, Malaysia \\ ${ }^{3}$ Milling and Processing Unit, Enginering and Processing Research Division, \\ Malaysian Palm Oil Board, 43000 Kajang, Selangor, Malaysia \\ ${ }^{4}$ Institute of Science, \\ Universiti Teknologi MARA, 40450 Shah Alam, Selangor, Malaysia \\ ${ }^{5}$ Faculty of Defence Science and Technology, \\ Universiti Pertahanan Nasional Malaysia, 57000 Sungai Besi, Kuala Lumpur, Malaysia \\ *Corresponding author: oskar@salam.uitm.edu.my
}

Received: 4 December 2016; Accepted: 1 December 2017

\begin{abstract}
Microbial Fuel Cell (MFC) is an alternative method of renewable energy which have gained considerable attention due to its capability to generate electricity and treat wastewater such as palm oil mill effluent (POME). MFC's mechanism on its electrochemical process is still lacking and further studies is needed. The objectives of this study are (1) to determine the compatibility of MFC device in generating electricity by using three different electrodes and (2) to study the effect of sodium hydroxide $(\mathrm{NaOH})$ to MFC's performance. In this work, the MFC device is associated with 3 different electrodes which are carbon brush (CB), carbon cloth (CC) and pre-treated carbon cloth (PCC) on its anode chamber. There are 2 types of substrates used in this experiment which are POME with the presence of bacteria (POME+) and POME without bacteria in it (POME-). The experiment was carried out for 120 hours and its power generation was monitored. The experimental result shows that PCC with POME+ yielded the highest power density of $49.88 \mathrm{~mW} / \mathrm{m}^{2}$ at 27 hours as compared to the others. In addition, CC with POME- has the highest chemical oxygen demand (COD) deduction which indicates the POME treatment was deducted by 45.93\%. $\mathrm{NaOH}$ affected the performance of MFC but is insignificant to influence the redox reaction of MFC.
\end{abstract}

Keywords: bio-electricity, fuel cell, wastewater treatment

\section{Abstrak}

Sel Bahan Bakar Mikrob (MFC) merupakan kaedah alternatif tenaga boleh diperbaharui yang mendapat perhatian yang baik kerana kemampuannya menjana elektrik dan merawat air kumbahan seperti sisa kilang minyak sawit (POME). Mekanisma MFC bagi proses elektrokimia masih kurang dan kajian lanjut diperlukan. Objektif kajian ini adalah (1) menentukan kesesuaian peranti MFC dalam menghasilkan elektrik dengan menggunakan tiga elektrod yang berbeza dan (2) untuk mengkaji kesan natrium hidroksida $(\mathrm{NaOH})$ kepada prestasi MFC. Dalam kerja ini, peranti MFC dikaitkan dengan 3 elektroda yang berbeza iaitu berus karbon (CB), kain karbon (CC) dan pra rawatan kain karbon (PCC) di ruang anodnya. Terdapat 2 jenis substrat yang digunakan dalam eksperimen ini iaitu POME dengan kehadiran bakteria (POME+) dan POME tanpa bakteria di dalamnya (POME-). 
Eksperimen ini dijalankan selama 120 jam dan penjanaan kuasanya dipantau. Keputusan eksperimen menunjukkan bahawa PCC dengan POME+ menghasilkan ketumpatan kuasa tertinggi $49.88 \mathrm{~mW} / \mathrm{m}^{2}$ pada 27 jam berbanding yang lain. Di samping itu, CC dengan POME- mempunyai permintaan oksigen kimia (COD) tertinggi yang menunjukkan rawatan POME berjaya sebanyak 45.93\%. NaOH mempengaruhi prestasi MFC tetapi tidak signifikan untuk mempengaruhi tindak balas redoks MFC.

Kata kunci: bio-elektrik, sel bahan bakar, rawatan air kumbahan

\section{Introduction}

In Malaysia, POME is a highly polluted wastewater produced by palm oil processing mills, which was usually treated in open pond system consist of cooling ponds, acidification ponds, anaerobic ponds and facultative ponds until its biological oxygen demand (BOD) meets the limit set by Malaysian Department of Environment (DOE) which is $5,000 \mathrm{mg} / 1$ [1] before discharging it into the water course [2]. POME anaerobic fermentation is a complex biochemical process in anaerobic condition where organic matters are degraded to methane and carbon dioxide in discrete steps involving the concerted action of myriad numbers of bacteria in several different metabolite groups of microorganism. The main pathways of anaerobic digestion are involved in 4 stages which are hydrolysis, acidogenesis, acetogenesis and methanogenesis [2].

Recently, the POME treatment process involving bacteria has gained some interest among many scientists and environmentalists, and usage of bacteria together in MFC is one of the alternatives for POME treatment. The application of MFC technologies is an alternative approach to wastewater treatment that uses by-product generated electricity [3]. In 2004, the relationship between electricity using MFCs and wastewater treatment was clearly forged when it was demonstrated that domestic wastewater could be treated to practical levels while simultaneously generating electricity [4]. Bioelectricity generation is a new approach for generating electricity from biomass using bacteria. Therefore, bacteria were further categorized by their ability to exogenously transfer electrons, called exoelectrogens that can produce power in an MFC [3]. Other names for exoelectrogens are electrogens, anoderespiring bacteria [5] and electrochemically active bacteria/microorganism [6]. Exogenously transfer electrons by bacteria are also known as e Extracellular Electron Transfer (EET) [5].

In the present study, the POME was autoclaved to eliminate any living microorganisms that potentially leading the experimental process to false result. The autoclaved POME was used as a substrate, there were two type of substrates that were used which is POME- and POME+. Each of the substrates was subjected with 3 different electrodes namely carbon brush (CB), carbon cloth (CC) and pre-treated carbon cloth (PCC). Mixed cultured exoelectorgens that was successfully isolated and cultured by our lab, was used in this experiment. $\mathrm{NaOH}$ was subjected in the MFC device and acted as reducing agent. The aims of this experiment were to determine the compatibility of MFC device in generating electricity by using three different electrodes, and also to study the effect of $\mathrm{NaOH}$ as reducing agent on 3 different electrodes that were used. The purpose to achieve the experiment's goals are to provide a basic understanding towards the electrochemical process of MFC device. By gaining this understanding, we could build a new MFC system that would enhance the power generation yields by the MFC devices and its performance.

\section{Materials and Methods}

The air cathode double-chambered MFC was made locally using acrylic fiber material with $100 \mathrm{~mL}$ of working volume for each component. The anode chamber (anaerobic) and cathode chamber (aerobic) were separated by a salt bridge compartment filled with molten $10 \%$ agarose with $4 \%$ potassium chloride salt [7] heated in a water bath which was allowed to be cooled and solidified in room temperature. The salt bridge assists in the proton transfer mechanism during the operational of MFC. The electrodes material used for anode and cathode were carbon cloth (Activated Carbon Fiber (ACF) Fabric, China) with the sizes of $3.0 \times 3.0 \mathrm{~cm}$ (used in both chambers) with projected area of $9.0 \mathrm{~cm}^{2}$ and carbon brush (Bosch Skil Dremel PG88, German) also with the sizes of $3.0 \times 3.0 \mathrm{~cm}$ (used in both chambers) with projected area of anode was $9.0 \mathrm{~cm}^{2}$, separately. The anode chamber is sealed to maintain its anaerobic condition. The electrodes close circuit was connected externally through copper wires to provide the permanent connection to external resistance of $1 \mathrm{k} \Omega$ resistor. The schematic diagram of MFC is shown in Figure 1 . 


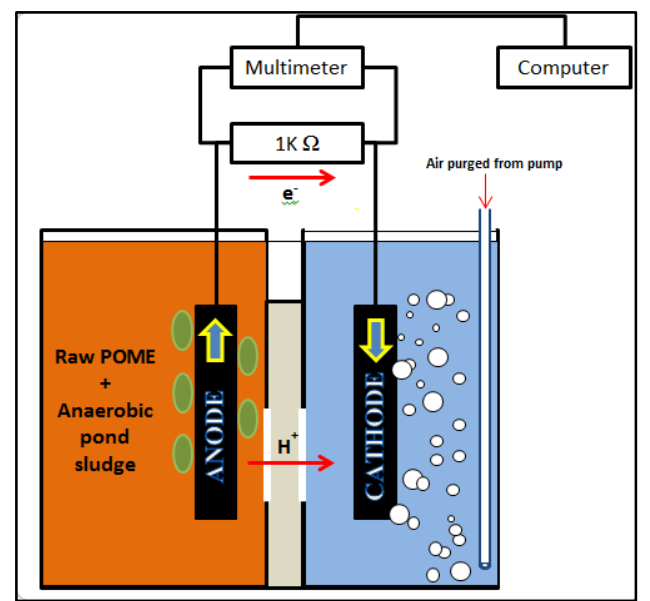

Figure 1. Schematic diagram of aqueous cathode double-chamber Microbial Fuel Cell (MFC)

The substrate used is autoclaved POME. A batch of 1.5 L raw POME was autoclaved for 15 minutes in temperature of $121{ }^{\circ} \mathrm{C}$ at $100 \mathrm{kPa}$ to eliminate living microorganisms entirely. The substrates were introduced with inoculum (acetogenic mixed cultured bacteria) and were prepared in $250 \mathrm{~mL}$ borosilicate glass reagent bottles with a mixing ratio of 1:10 (20 mL of inoculum to $180 \mathrm{~mL}$ of autoclaved POME) with a total of 6 bottles. The $\mathrm{pH}$ of substrates was controlled by using sodium hydroxide $(\mathrm{NaOH})$ that maintained $\mathrm{pH} 6.8 \pm 0.2$. Then, each $250 \mathrm{~mL}$ bottle transferred $100 \mathrm{~mL}$ of substrate into $100 \mathrm{~mL}$ borosilicate glass reagent bottles as controlled and calibrate sample. After 24 hours of fermentation process, the leftover substrates of $100 \mathrm{~mL}$ in each $250 \mathrm{~mL}$ bottle was used in MFC's operation.

In preparing PCC, the cloth was soaked in a pure acetone for 24 hours. After soaking overnight, the cloth was then soaked in ammonium peroxydisulfate $(200 \mathrm{~g} / \mathrm{mL})$ and concentrated sulfuric acid $(100 \mathrm{~mL} / \mathrm{L})$ for 15 minutes. The furnace was set up to $450{ }^{\circ} \mathrm{C}$ before the cloth was heat-treated for 30 minutes. This pretreated process was done as to increase the surface area of the carbon cloths that are used.

The electrode output voltage was recorded every 1 hour with digital multimeter with data logger (DM620, 50,000 Count Logger DMM and UT803, UNI-T). From these data, power generation was calculated using power density normalized by surface area $\left(\boldsymbol{P}_{\boldsymbol{A}}, \mathrm{Wm}^{-2}\right)[8]$ using the equation 1 below;

$$
P_{A n}=\frac{V^{2}}{A_{A n} R}
$$

where $\boldsymbol{A}=$ total area of anode electrode $\left(\mathrm{m}^{2}\right), \boldsymbol{A} \boldsymbol{n}=$ Anode, $\boldsymbol{P}=$ power $(\mathrm{W}), \boldsymbol{V}=$ the potential $(\mathrm{V})$ and $\boldsymbol{R}=$ external resistance $(\Omega)$. The data collection was analyzed and graphs were plotted based on the equation 1 .

The COD of the anode substrates was determined by using COD cell test kit (20 - 1,500 $\mathrm{mLL}^{-1}$ range: Hach, USA), digested by using COD reactor (Hach DRB 200, USA) and measured using COD spectrophotometer (Hach DR2800, USA) where COD reading was taken. The initial COD reading was analyzed by taking $2 \mathrm{~mL}$ of substrate before filling it in MFC devices. The second COD reading was taken from the MFC anode chamber and the calibrate sample on the final day of the experiment. The COD reduction efficiency ( $\mathbf{y})$ can be calculated as the ratio between the removed and initial effluent COD [8] using the following equation 2 as reported in [9].

$$
\eta=\frac{\mathrm{COD}_{0}-\mathrm{COD}_{\mathrm{t}}}{\mathrm{COD}_{0}}
$$


where $\mathrm{COD}_{\mathrm{o}}=$ initial COD of the effluent in the anode chamber, $\mathrm{mgL}^{-1}$ and $\mathrm{COD}_{\mathrm{t}}=\mathrm{COD}$ of the effluent in the anode chamber at measured time. The data is collected and analyzed.

Environmental Scanning Electron Microscopy (Quanta 450 FEG ESEM, USA) was used to observe the biofilm formed on the anodic carbon brush's (ACB) surface. A cut ACB was soaked for 4 hours in $4 \%$ glutaraldehyde phosphate buffer solution for fixation process. Then, the ACB was rinsed in distilled water before the sample was observed under ESEM at $20 \mathrm{kV}$.

\section{Results and Discussion}

The concept of MFC is the association of bacteria's metabolism activity as catalyst to enhance the redox process in the MFC, which means without the presence of bacteria in the fuel cell, there are still a small number of electrons will be transferred. The redox process, or dissolve of hydrogen and oxygen, between the electrodes used still occurred, although there are no bacteria subjected into the MFC. There are lots of studies regarding fuel cell without bacteria association that achieved a greater success such as polymer electrolyte membrane fuel cell (PEMFC) [10] and alkaline fuel cell (AFC) [11]. However, MFC is the most unique and versatile system amongst all fuel cells due to its ability to treat wastewater, although its power generation is low as compared to other fuel cell systems. Overall, the result of the experiment is parallel as the theory which are the association of bacteria in the MFC enhanced the power generation and the redox reaction between two electrodes showed some results and produced small amount of electricity.

Voltage reading was recorded, where power and current densities were calculated. From Figure 2, the highest voltage generated is by PCC2. As for $\mathrm{CB} 1$ and PCC1 are the lowest voltage generation compared to all the electrodes material used. In the graph, by comparing the materials that were introduced with bacteria $(\mathrm{CB} 2, \mathrm{CC} 2$ and PCC2) yielded higher voltage generations as compared to the materials that were not introduced (CB1, CC1 and PCC1) with the bacteria. If we compare the average power generated of 72 hours between the materials, the highest voltage generation that were produced by the materials that were not introduced by the bacteria is only $2.0 \mathrm{~mW} / \mathrm{m}^{2}$ at most on average. The highest power generated peak is produced by PCC2 at 26 hours, which is $49.55 \mathrm{~mW} / \mathrm{m}^{2}$. If we compare the materials in POME+ (straight line), the highest power generated is yielded by PCC2 and the lowest is CB2, with the average power generated of $38.38 \mathrm{~mW} / \mathrm{m}^{2}$ and $8.69 \mathrm{~mW} / \mathrm{m}^{2}$, respectively. If we compare the materials that subjected in POME- (dotted line), the highest power generated is yielded by $\mathrm{CC} 1$ and the lowest is PCC1, with the average power generated of $1.9 \mathrm{~mW} / \mathrm{m}^{2}$ and $0.28 \mathrm{~mW} / \mathrm{m}^{2}$, respectively as shown in Figure 2. It is proven that the association of exoelectrogens bacteria in MFC device enhanced the power generation of the MFC system. There is lack of studies that compares this factor of presence and absence of bacteria, due to vast studies which have proven the ability of MFC to generate electricity. This work is not entirely to test the ability of MFC to produce electricity but instead to determine whether the electricity that was produced is really the work of the bacteria metabolism activity, or it is actually produced by other factors. The result that is shown in Figure 2, it is proven that electricity that was produced is due to the activity of bacteria metabolism. This result aligns with most of the studies regarding MFC [12 - 14].

There are 3 types of exoelectrogens which are mediator, mediatorless and nano-wired [3]. Depending on the type of bacteria that is associated with the MFC, the result may be varied. In one case, in a single MFC device there may be only single type of exoelectrogens metabolize in the system, on the other hand, all types of exoelectrogens are working together and co-existing in a single MFC system to generate electricity. There are many types of mediator used in the previous studies, and most common mediator used was glucose $[4,15,16]$. 


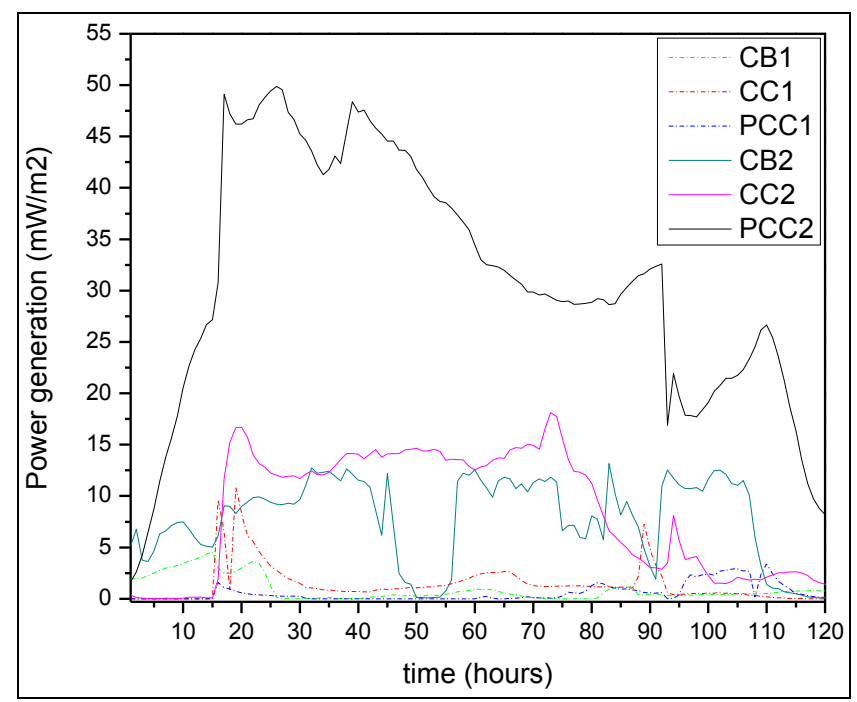

Figure 2. Power Generations with POME+ and POME- exoelectrogens on materials used

$\mathrm{NaOH}$ is commonly used in controlling the substrate's pH value [17 - 19]. The problem comes when $\mathrm{NaOH}$ itself may act as a reducing agent or mediator to the exoelectrogens that present in the MFC device. In different cases, a collaboration of $\mathrm{NaOH}$ which contributed in generating additional electrons is helpful in enhancing the power generation of the MFC system, but in this case, it is not, because this experiment is solely to determine the true potential of mediatorless exoelectrogens of yielding the highest power possible. This experiment was also conducted to determine whether the $\mathrm{NaOH}$, that was used in maintaining the $\mathrm{pH}$ value of the substrate, may influence the result of power generation that generated by the exoelectrogens during the experimental process. From Figure 3 and Figure 4, there are two arrows aligned with the $\mathrm{x}$-axis, these arrows represent the period of when the $\mathrm{NaOH}$ was inserted in the MFC's anode chamber. At 15 hours of the experiment, the substrate in the anode MFC chamber was introduced with 5 pellets of $\mathrm{NaOH}$ and the substrate was later introduced with another 1 pellet of $\mathrm{NaOH}$ at 88 hours. In the Figure 3, power generations by all electrodes were increased when the $\mathrm{NaOH}$ was first introduced, then the power generations started to decrease. The power generations continued to increase when the substrates were introduced with $\mathrm{NaOH}$ for the second time. Also in the graph, the power was only generated when the $\mathrm{NaOH}$ was introduced in the substrates, but after 1 day, the power generation dropped to almost $1 \mathrm{~mW} / \mathrm{m}^{2}$ which indicates no bacteria metabolism activity.

In Figure 4, power generations by all electrodes increased when the $\mathrm{NaOH}$ was first introduced, then the power generations started to maintain. As compared to power generations of POME- exoelectrogens, the power generated by POME+ exoelectrogens gradually decreased, but POME- exoelectrogens rapidly decreased, which proved the possibility of bacteria metabolism activity were taking place on the electrodes in POME+. Exoelectrogens' metabolism activity produced electrons and hydrogens. Both electrons and hydrogens travelled to the cathodic chamber through proton exchange membrane (salt bridge) and will reduce to water which led the circuit to complete [3]. The power generations continued to increase slowly when the substrates were introduced with $\mathrm{NaOH}$ for the second time, then the power generations decreased after a few hours. In the graph, if we compared all three electrodes' power generations, we can see a huge difference between PCC 2 and both CC2 and CB2. The difference between them is around $35 \mathrm{~mW} / \mathrm{m}^{2}$ in average, which means 3 times higher. The difference between CC2 and CB2 are small but CC2 still produced higher power generation. If we compare Figure 3 and Figure 4, there were almost no power generated by POME- exoelectrogens, but it is clear in Figure 4, there are power that was generated by the POME+ exoelectrogens in the MFC device. 


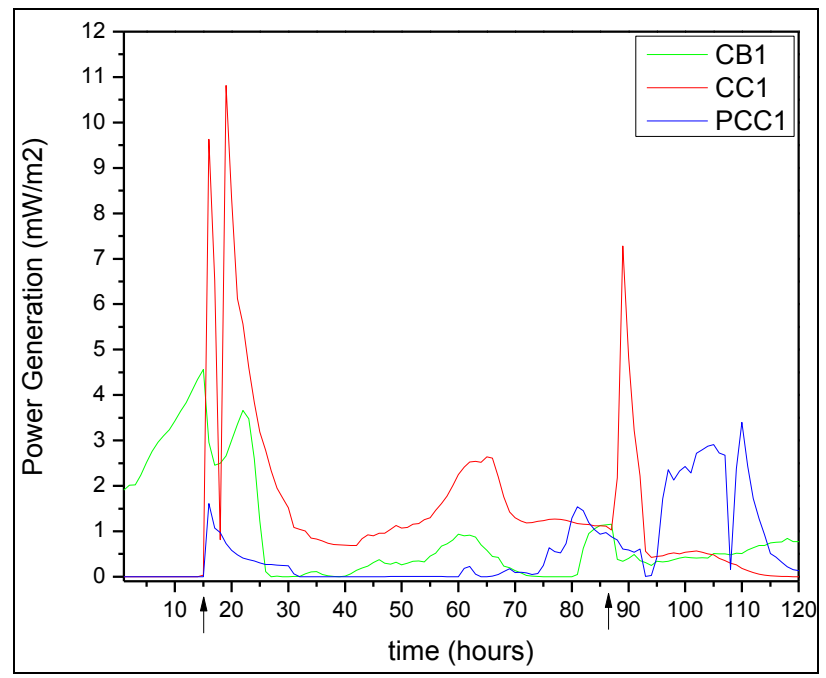

Figure 3. Effect of $\mathrm{NaOH}$ in POME- exoelectrogens' power generation $\mathrm{CB} 1, \mathrm{CC} 1$, and $\mathrm{PCC} 1$

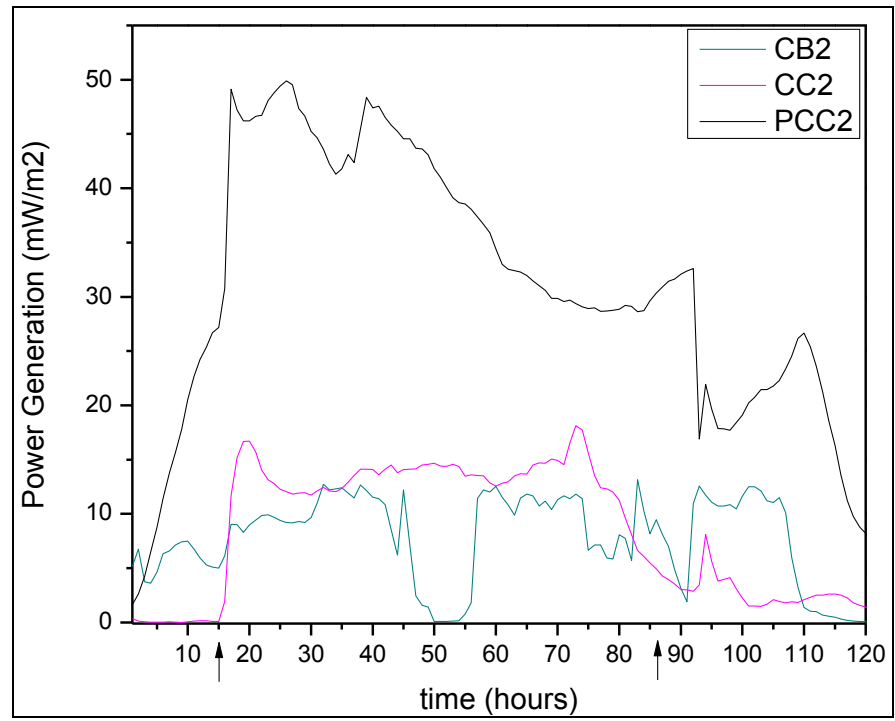

Figure 4. Effect of $\mathrm{NaOH}$ in POME+ exoelectrogens's power generation $\mathrm{CB} 2, \mathrm{CC} 2$, and $\mathrm{PCC} 2$

Most related MFC studies were using $\mathrm{NaOH}$ or $\mathrm{Ca}(\mathrm{OH})_{2}$ as their $\mathrm{pH}$ controller but did not attend to study the interaction between the $\mathrm{pH}$ controller, that they were using, and the inoculum in the MFC device. A study done by Patil et al., $1 \mathrm{~N} \mathrm{NaOH}$ was used to control their substrate's $\mathrm{pH}$ value [19]. In another study, they did not just use the $\mathrm{NaOH}$ to control $\mathrm{pH}$ value of the substrates but also, they washed the electrodes that were used with $\mathrm{NaOH}$ and $\mathrm{HCl}$ [20]. In this work, $\mathrm{NaOH}$ also was used as a $\mathrm{pH}$ controller and from Figure 3 it shows a clear picture of the effect of $\mathrm{NaOH}$ to the power generated in MFC devices. However, the power peaked for a few hours then maintained back to its current power generation. It is proven that the use of $\mathrm{NaOH}$, as $\mathrm{pH}$ controller, in MFC system affected the power generation as shown in Figure 3. In Figure 4, the $\mathrm{NaOH}$ affected the power generation, but as compared to Figure 3 the power that peaked maintained and decreased gradually. This strongly proved that the bacteria activity taken place after the effect of $\mathrm{NaOH}$ to the substrates wore off. 
COD deduction done by POME-'s electrodes are relatively higher than POME+'s electrodes (Table 1). The highest COD deduction was done by $\mathrm{CC} 1$ with deduction of $45.93 \%$ and the lowest deduction is $22.73 \%$ by CB2. COD control, which is the POME sample that is not subjected in MFC device, of the experiment is $4.28 \%$. There are a clear difference between COD deduction of control and both POME+ and POME- electrodes which proved the MFC's theory on its ability to increase the COD deduction in POME treatment [3]. Although there are no bacteria subjected in POME- but the COD deduction is better than POME+, which is due to the increment of COD in POME+ after the POME sample was fermented with bacteria after 24 hours. In "initial COD" column, an increment of $60 \%$ of COD on POME+ after it was fermented for 24 hours. This increment is the factor of why the COD deduction done by POME- is better than POME+, but in terms of amount $(\mathrm{mg} / \mathrm{L})$ of COD deduction, POME+ deducted more than POME-, relativity. The highest amount of COD that was deducted is $21166 \mathrm{mg} / \mathrm{L}$ which is done by PCC 2 and the lowest amount of COD deduction is done by CB2 which is $15033 \mathrm{mg} / \mathrm{L}$. In most MFC studies, they calculated the coulombic efficiency (CE) as to determine the performance of MFC [21], but in this work, CE is not calculated because the objective of this work is not to determine the performance of the MFC but to compare the material used in the MFC devices.

Table 1. COD deduction after 120 hours of MFC

\begin{tabular}{lcccc}
\hline Electrode & $\begin{array}{c}\text { Initial COD } \\
(\mathbf{m g} / \mathbf{L})\end{array}$ & $\begin{array}{c}\text { Final COD } \\
(\mathbf{m g} / \mathbf{L})\end{array}$ & $\begin{array}{c}\text { Deduction } \\
(\mathbf{m g} / \mathbf{L})\end{array}$ & $\begin{array}{c}\text { Deduction } \\
(\boldsymbol{\%})\end{array}$ \\
\hline Control & 38200 & 36566 & 1634 & 4.28 \\
CB1 & & 23633 & 16067 & 40.47 \\
CC1 & 39700 & 21467 & 18233 & 45.93 \\
PCC1 & & 24033 & 15667 & 39.46 \\
CB2 & & 51100 & 15033 & 22.73 \\
CC2 & \multirow{2}{*}{66133} & 46100 & 20033 & 30.29 \\
PCC2 & & 44967 & 21166 & 32.0 \\
\hline
\end{tabular}

ESEM was used to observe the ACB's surface on both POME- and POME+. In ACB in POME- (Figure 5), there were a very small number of bacteria detected which did not contributed in generating electricity. In ACB in POME+ (Figure 5), there were lots of numbers of bacteria detected that formed a biofilm on the ACB which contributed in generating electricity. The comparison between both factors is clear and proven that the association of bacteria in MFC to generate electricity.
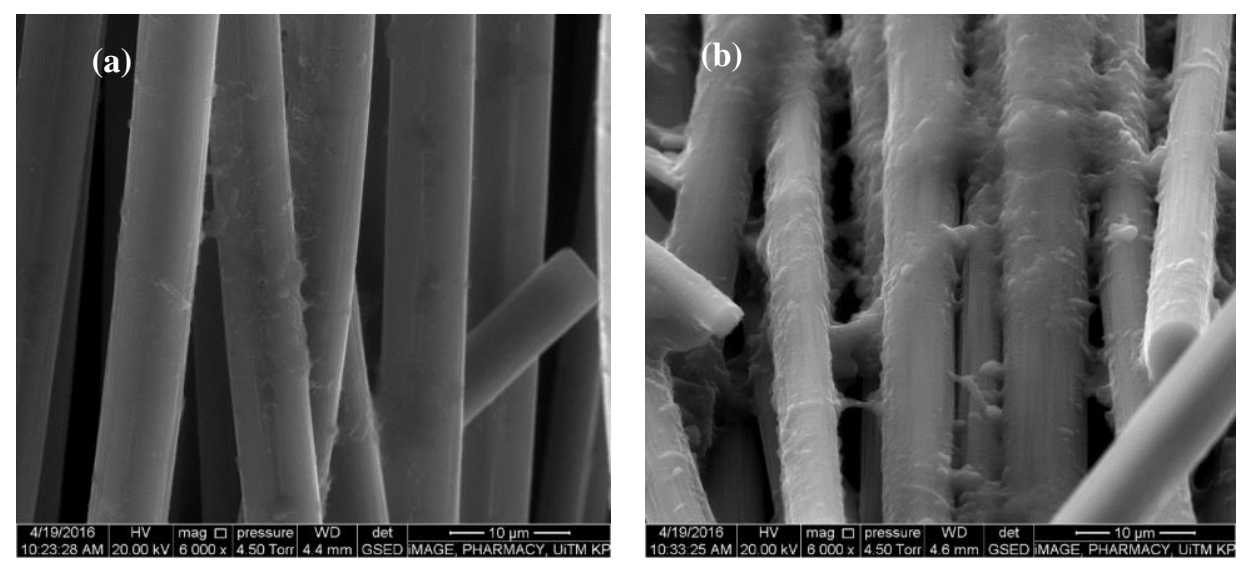

Figure 5. ESEM images of microorganisms' attachment on ACB's surface at day 5 (a) ACB from POME- (b) ACB from POME+ 


\section{Conclusion}

In conclusion, the result is as predicted. The comparison between two substrates used, which are POME- and POME+, shows a clear result that associations of bacteria in MFC devices generate a better power generation. On average, the highest power generated is $38.38 \mathrm{~mW} / \mathrm{m}^{2}$, which yielded by POME+ PCC2. There are only a small portion of power generated in all POME- substrates but the power that were generated is not significant. CC1 with POME- has the highest chemical oxygen demand (COD) deduction efficiency which indicates the POME treatment is deducted by $45.93 \%$. The $\mathrm{pH}$ controller $(\mathrm{NaOH})$ used did gave a kick start in power generations but in a few hours the effect of $\mathrm{NaOH}$ on the power generation decrease rapidly.

\section{Acknowledgement}

The authors would like to thank the Ministry of Education (MOE), Malaysia and University of Technology MARA (UiTM) and Malaysia Palm Oil Board (MPOB) for funding (ERGS (600-RMI/ERGS 5/3 (5/2013)) and GSAS) this project.

References
1. Malaysian Federal Subsidiary Legislation (1978). Environmental quality act 1974. Access from https://www.doe.gov.my/portalv1/wpcontent/uploads/2015/01/Environmental_Quality_Scheduled_Wastes Regulations_2005_-_P.U.A_294-2005.pdf

2. Andrew, Y. K. C. and Manaf, F. Y. A. (2013). Fermentation pathway for palm oil mill effluent. Palm Oil Engineering Bulletin, 109: 13-23.

3. Logan, B. E. (2008). Microbial fuel cells. John Wiley \& Sons, Inc, United Kingdom: pp.200.

4. Liu, H. and Logan, B. E. (2004). Electricity generation using an air-cathode single chamber microbial fuel cell in the presence and absence of a proton exchange membrane. Environmental Science and Technology, 38(14): 4040-4046.

5. Torres, C. I., Marcus, A. K., Lee, H. S., Parameswaran, P., Krajmalnik-Brown, R. and Rittmann, B. E. (2010). A kinetic perspective on extracellular electron transfer by anode-respiring bacteria. FEMS Microbiology. Reviews, 34: 3-17.

6. Samir, K. K., Rao, Y. S., Zhang, T. C., Budhhi, P. L., Tyagi, R. D. and Kao, C. M. (2010). Bioenergy and biofuel from biowastes and biomass. Institution American Society Civil Engineering, 6: 116-126.

7. Nair, R., Renganathan, K., Barathi, S. and Venkatraman, K. (2013). Performance of salt-bridge microbial fuel cell at various agarose concentrations using hostel sewage waste as substrate. International Journal of Advance Research Technology, 2 (5): 326-330.

8. Logan, B. E., Hamelers, B., Rozendal, R., Schroder, U., Keller, J., Freguai, S., Aelterman, P., Verstraete, W. and Rabaey, K. (2006). Microbial fuel cells: Methodology and technology. Environment Science and Technology, 40(17): 5181-5192.

9. Baranitharan, E., Khan, M. R. and Prasad, D. (2013). Treatment of palm oil mill effluent in microbial fuel cell using polyacrylonitrile carbon felt as electrode. Journal of Medical and Bioengineering, 2(4): 252-256.

10. Garraín, D. (2011). Polymer electrolyte membrane fuel cells (PEMFC) in automotive applications: environmental relevance of the manufacturing stage. Smart Grid Renewable Energy, 2(2): 68-74.

11. Alhassan, M. and Garba, M. U. (2006). Design of an alkaline fuel cell. Leonardo Electronic Journal of Practices and Technologies, 9: 99-106.

12. Bond D. R. (2010) Electrodes as electron acceptors, and the bacteria who love them. In: Barton L., Mandl M., Loy A. (eds) Geomicrobiology: Molecular and environmental perspective. Springer, Dordrecht: pp. 385-399.

13. Logan, B. E. and Regan, J. M. (2006). Electricity-producing bacterial communities in microbial fuel cells. Trends Microbiology, 14(12): 512-518.

14. Gallert, C. and Winter, J. (2005). Bacterial metabolism in wastewater treatment systems. Wiley-VCH, Weinheim, Germany: pp. 1-48.

15. Alalayah, W. M., Kalil, M. S., Kadhum, A. A. H., Jahim, J. M. and Alauj, N. M. (2008). Hydrogen production using Clostridium saccharoperbutylacetonicum N1-4 (ATCC 13564). International Journal Hydrogen Energy, 33(1): 7392-7396. 
16. Biffinger, J. C., Byrd, J. N., Dudley, B. L. and Ringeisen, B. R. (2008). Oxygen Exposure promotes fuel diversity for shewanella oneidensis microbial fuel cells. Biosensors and Bioelectronics, 23: 820-826.

17. Lang, L. Y. (2007). Treatability of palm oil mill effluent (POME) using black liquor in an anaerobic Treatment Process. Thesis Master of Science, Universiti Sains Malaysia, Malaysia.

18. Rajesh, J., Khac, U. Do, Adish, S., Ick-Tae, Y. and Kaliappan, S. (2012). A novel method of sludge pretreatment using the combination of alkali. Journal of Enviromental Biology, 33: 249-253.

19. Patil, S. A., Harnisch, F., Koch, C., Hübschmann, T., Fetzer, I., Carmona-Martínez, A. A., Müller, S. and Schröder, U. (2011). Electroactive mixed culture derived biofilms in microbial bioelectrochemical systems: The role of $\mathrm{pH}$ on biofilm formation, performance and composition. Bioresources. Technology, 102(20): 96839690.

20. Puig, S., Serra, M., Coma, M., Cabré, M., Balaguer, M. D. and Colprim, J. (2010). Effect of pH on nutrient dynamics and electricity production using microbial fuel cells. BioresourcesTechnology, 101: 9594-9599.

21. Zhang, X., He, W., Ren, L., Stager, J., Evans, P. J. and Logan, B. E. (2015). COD removal characteristics in air-cathode microbial fuel cells. Bioresources Technology, 176: 23-31. 